\title{
Practice Teaching Reform and Exploration of Logistics Management Major in the Transformation and Development of Local Undergraduate Universities
}

\author{
Xiao Hu \\ Henan University of Engineering, Zhengzhou 451191, Henan, China.
}

Abstract: With the transformation and development of local undergraduate universities, higher requirements are put forward for the training of logistics management professionals. At present, the cultivation of logistics management professionals should pay more attention to practical teaching, and comprehensively improve the practical ability of professionals. At the same time, personnel training should be combined with the actual situation of local economic and social development, guided by the market demand, and comprehensively increase the training of applied talents, so that logistics management professionals can smoothly obtain employment and quickly meet the demand of professional human resources in the market. This paper focuses on the practical teaching reform of logistics management major in the transformation and development of local undergraduate universities.

Keywords: Local Undergraduate Universities; Transformation and Development Period; Logistics Management Major; Practical Teaching; Reform

Under the new situation, China's higher education has been popularized. In order to comply with the development trend of higher education, local undergraduate universities have carried out transformation and reform, and attached great importance to cultivating a number of compound talents with solid professional theoretical foundation and strong practical operation skills. Based on this, we must focus on practical teaching. Taking logistics management major as an example, this paper discusses some thoughts on practical teaching reform in the transformation and development of local undergraduate universities.

\section{Problems in practical teaching of logistics management major}

\subsection{The teaching mode is out of date, ignoring the importance of practical teaching}

Although our country vigorously advocates quality education and actively promotes the new curriculum standards, many undergraduate universities still follow the examination oriented education mode and position themselves according to the academic talent training ideas. Therefore, the professional orientation, syllabus, curriculum and teaching content are still affected by the examination oriented education system, paying attention to the explanation of theoretical knowledge and ignoring the importance of practical teaching, as a result, the lack of deep cognition ability and post adaptability of talent saffect the sustainable development of students.

\subsection{Lack of strong teachers resources}

As an emerging industry, logistics industry has a short development time. Many colleges and universities only set up logistics management major at the beginning of the 21 st century, which is still in the development stage, and does not have sufficient comprehensive strength and strong competitive technology and talent advantages. Most colleges and universities are mainly young teachers. After graduation of master's degree or doctor's degree, they directly go to the university for employment, and have no practical work experience in enterprises and production line, let alone the ability of product research and development, enterprise management and technical service. All these have seriously affected the quality and level of practical teaching of logistics management major.

Copyright $(2020 \mathrm{Xiao} \mathrm{Hu}$

doi: 10.18686/ahe.v4i10.2892

This is an open-access article distributed under the terms of the Creative Commons Attribution Non-Commercial License (http://creativecommons. org/licenses/by-nc/4.0/), which permits unrestricted non-commercial use, distribution, and reproduction in any medium, provided the original work is properly cited. 


\subsection{Lack of perfect school enterprise cooperation mechanism}

The purpose of school enterprise cooperation is to enable colleges and universities to cultivate high-quality talents required by enterprise production and management according to the needs of industry and enterprise development, which requires mutual support and common development between universities and enterprises. However, many enterprises cooperating with colleges and universities are lack of education consciousness. They mostly meet the needs of human resources through school enterprise cooperation, and do not play their own educational function, and lack of support and integration of colleges and universities. Secondly, the school enterprise cooperation mainly focuses on post practice. The agreements signed by both sides are lack of substance and operability, and lack of planning and design of multi practice content and assessment, which leads to the poor quality of school enterprise cooperation and ultimately affects the quality and level of talent training.

\section{Specific countermeasures for the reform of practical teaching of logistics management major in the transformation and development of local under graduate universities}

\subsection{Keeping pace with the times and optimize the practical teaching content of logistics management major}

In the process of transformation and development, local undergraduate universities should follow the pace of local economic and social development, enrich and optimize teaching content in time, so as to ensure some practical teaching content can walk in the forefront of teaching materials, and lay a solid foundation for students' follow-up professional courses by actively applying the latest teaching software. Secondly, in the design of practical teaching, we should pay attention to the connection of local characteristics. For example, in developed agricultural areas, the logistics management curriculum should increase the practice of grain logistics and fresh agricultural products logistics, in order to highlight the service performance of logistics management major to local economic and social development, so as to make great contribution to local economic development.

\subsection{Innovating the practical teaching method of logistics management major}

Firstly, adopting project driven teaching method. Under the concept of comprehensive quality education, China attaches great importance to the cultivation of compound talents. In the teaching process of logistics management major, teachers should guide students to participate in the actual logistics projects. Based on the actual situation of students' professional course learning and professional quality training, highlight the self-education design and education process realization of college students, and carry out group cooperation and discussion based on the real logistics projects learning, so that teachers can complete the evaluation according to the specific performance of students. Secondly, the internal management of the project should penetrate the enterprise research and development as well as the awareness and means for team management, and use KPI performance appraisal to create a real enterprise and professional atmosphere for students to learn as professionals. However, in the application of project driven teaching method, teachers should play their own role of organization, guidance, answering questions and assessment, fully respect the students' teaching dominant role, so as to guide and encourage students to carry out innovation and entrepreneurship. If the projects completed by students have achieved significant results, social funds can be attracted to directly carry out the incubation of achievements. Teachers can also sort out the students' practice reports and save them in the case library. When carrying out the teaching of "Logistics Cost Management", they can use the real case data in the case library to let students calculate the enterprise logistics cost.

Secondly, innovative use of sand table teaching. As we all know, classroom teaching time and energy are very limited, teachers can actively play the role of teaching in the second classroom and after class. By sand table games, the operation and management of third-party logistics enterprises can be simulated, so that students experience the whole process of goods preparation, transportation, storage, order and distribution, and formulate operation and management strategies by themselves. It guides students to deepen problems of enterprises in the actual transportation, the impression of emergencies in the industry, in order to cultivate students' ability to analyze and solve problems independently, and have a deep understanding of the industry development and enterprise post work.

\subsection{Improving the structure of the teaching staff and strengthen the teaching resources}

At present, most of the local colleges and universities have the problem of imperfect structure of teaching staff, which seriously affects the quality and level of personnel training. Based on this, we should pay attention to strengthen the construction of teaching staff. First of all, invite logistics industry experts and scholars, enterprise elites, senior engineers and managers with excellent professional quality, strong teaching ability and rich practical experience to work as part-time teachers in colleges and universities, establish flexible employment mechanism, and build a perfect full-time and part-time teacher team. Secondly, we should strengthen the training of in-service teachers, deepen the school enterprise cooperation mode, and 
focus on building a "double qualified" teacher team, in order to provide opportunities and platforms for teachers to further study and temporary training, as well as encourage teachers to actively provide technical services for enterprises, accumulate work experience, and continuously improve practical teaching ability. In addition, we should pay attention to the reform of the evaluation standards of teachers' professional title evaluation and promotion, so as to provide teachers with broader development space, and then be able to devote themselves to the teaching work.

\subsection{Improving the mechanism of student assessment and evaluation}

Firstly, innovative use of "double certificate system". Under the new situation, logistics management major of universities should regard the theoretical examination and skill examination as the requirements of graduation examination. In the teaching process, students should be encouraged and organized to take part in the national logistics division, customs declaration certificate and other professional skills level and professional qualification examination, so as to lay a solid foundation for enhancing students' work ability and employment ability.

Secondly, the evaluation mechanism based on ability assessment should be constructed. In the traditional examination oriented education system, written examination is the main method, which is not conducive to the improvement of students' practical ability. Based on this, in order to improve the importance of practical teaching, we can establish an evaluation mechanism based on ability assessment, combining written test with skill test. For those professional courses with strong practicality, the multiple assessment methods should be adopted such as written test, practical operation and oral test, and provide evaluation results based on students' actual operation and accuracy of answering questions, so as to guide students to attach great importance to practice study.

\subsection{Deepening school enterprise cooperation}

Firstly, a perfect practice teaching system outside the school should be built. Many colleges and universities arrange students to go to logistics enterprises for observation and study only at senior stage. But at this time, students have great pressure on graduation thesis and employment, and they are unfamiliar with the working environment and content of enterprises, which leads to resistance and boredom. Based on this, colleges and universities should reform the practice system outside the school, set up in different grades, and organize students to visit enterprises, internship, research, rotation practice and other activities.

Secondly, school enterprise cooperation establishes outside school practice base. Under the new situation, schools and enterprises should jointly invest in the establishment of outside school training bases. Teachers transfer some professional courses to enterprises, and carry out teaching according to the actual situation of enterprises, so as to improve the teaching effect. Next, the enterprise selects senior engineers and professional backbones to serve as the guidance teachers of students' thesis, and cooperates with teachers in the school to jointly guide students' thesis writing, in order to ensure that the data of students' graduation thesis is true and closely related to the actual situation of enterprises. In addition, it is necessary to give full play to the talent advantages of colleges and universities, in order to provide professional services and project research services for enterprises. Moreover, schools and enterprises should cooperate to develop professional core courses, compile teaching materials, and truly improve the quality and level of practical teaching.

\section{Conclusion}

To sum up, practical teaching is an important part of logistics management specialty, which should be attached great importance by the local undergraduate universities. Combined with the actual needs of local economic and social development for logistics talents, it is necessary to clarify the professional orientation and teaching objectives, build a perfect practical teaching system, and create new teaching models with teacher resources enhancement, as well as deepen school enterprise cooperation, so as to jointly cultivate high-quality logistics management professionals in line with social development demand.

\section{References}

1. Xu Q. Exploration and practice of applied innovative talents training mode for logistics management major in application oriented universities. Value Engineering 2016; (36): 165-167.

2. Chen C, Li SZ. Discussion on practical teaching of logistics management major in local universities — Take Yangtze University as an example. Journal of Changjiang University: Social Science Edition 2016; (3): 90-92.

3. Jia WL, Li PL. Practice teaching reform of logistics management major in the transformation and development of local universities. Logistics Technology 2015; (012): 46-49.

4. Zhang QQ. Research on practical teaching reform of logistics management major in application oriented universities under the background of intelligent logistics. Time Economy and Trade 2019; (33): 121-122. 